\title{
The Importance of Disaster Response Awareness for Tourism Object Managers in West Sumatra
}

\author{
Pande Made Kutanegara ${ }^{1}$, Retnaningtyas Susanti ${ }^{2}$, Heriani ${ }^{3}$ \\ ${ }^{1}$ Anthropology Departmen, Faculty of Cultural Science, Universitas Gadjah Mada \\ 2Tourism Department, Faculty of Tourism and Hospitality, Universitas Negeri Padang \\ ${ }^{3}$ Public Administration Department, Universitas Terbuka \\ Coresponding Author: sretnaningtyas@yahoo.com
}

\begin{abstract}
Disaster is one of the main threats to tourism around the world. There are various kinds of disasters, ranging from terrorist attacks; social, cultural and political issues; disease outbreaks, and natural phenomena (floods, landslides, tsunamis, earthquakes and storms). One of the disasters being experienced by all tourism managers in West Sumatera is earthquakes. Disasters can occur and threaten the sustainability of a tourist attraction. The threat of disaster has an impact on tourist visits, so an effort is needed to prepare tourism managers to deal with it. The tourism industry is an economic activity that is highly dependent on image, when a tourist attraction fails to face a disaster, tourists are reluctant to visit the place. The methods used are interviews, observations, and literature studies that can help answer research questions. The key informants in this study were members of the tourism management in West Sumatra Province. The results showed that each tourist destination has a different threat of disaster from other areas, so the response required by the manager is also different. In the case of the earthquake, the response to the disaster cannot be overcome by all tourist destination managers, all experiencing the same conditions. Developed and developing tourist destinations need the same amount of time to deal with this disaster. The recommendation of this study is the importance of understanding disaster response by all tourist destination managers, so that the required recovery period is not too long, and tourism can return to its normal operation.
\end{abstract}

Keywords: tourism, tourism manager, disaster, disaster response, destination

This work is licensed under a Creative Commons Attribution-ShareAlike 4.0 International License.

\section{INTRODUCTION}

There are several studies that show that tourism and disasters have complex systems. In various forms of disasters, whether natural, pandemic (disease outbreaks), and other manmade disasters, tourism is always the main victim. The study of the impact of disasters on the performance of the tourism industry is relatively new. Although, several important studies have shown their disastrous impact on tourism, such as: hurricanes, floods and tsunamis, earthquakes, volcanic eruptions and forest fires. Studies have also been carried out on nonnatural disaster events, such as foot and mouth disease in the UK, and SARS in ASIA.

Efforts to understand the impact of disasters on the performance of the tourism industry, need to start by defining and conceptualizing the interaction. Structural analysis of the impact of disasters needs to be viewed from different perspectives, because in fact the nature of disasters is always related to responses from the tourism industry and the government as policy owners. Response is an important part of the impact of a disaster, as it determines the length of time that tourism managers must pass.

Disasters are a big threat to tourism. Becken (2012) concluded that the threat of disaster becomes one of the bases for "preparing for the future", by means of risk management so as to create risk reduction against these threats. This is very relevant to the principles of tourism 
whose growth is tied to the surrounding conditions (Buckley, et al, 2015).

The threat of disaster is a situation that can occur in the future and can affect tourism development. Efforts that can be made to reduce the number of hazards are to reduce vulnerability and increase the durability of tourist destinations. There are four categories of disaster threat that are relevant to tourism, namely: (i) extreme weather and climate change; (ii) geophysical hazards, (iii) environmental degradation, and (iv) man-made hazards in terms of technology and health. Tourism is currently one of the sectors most affected by disaster. The tourism sector, unlike other economic activities directly affected by disasters because tourism is an interaction, so its social impact is broader. Natural disasters are things that are outside human planning which will usually result in loss both material and nonmaterial. Disaster management in anticipation of a bigger impact is the obligation of the parties involved.

\section{LITERATURE REVIEW}

Lack of recovery efforts for the general public in Indonesia as tourists and tourism managers, causing problems in post-disaster life (Nugroho, 2013). People are still afraid of traveling, and managers are still obliged to close their businesses. The tourism industry is a sector that greatly benefits Indonesia because it has the potential for multiple impacts (Cholik, 2017; Mariyono, 2017). Tourism is an important element of the contemporary economy (Debski, 2017). One of them is that local revenue in an area that has tourist destinations will have the potential to increase as well (Incera \& Fernández, 2015). The development of tourism in Indonesia cannot be separated from the development of tourism at the local level (Oktavio, 2017; Sutanto, 2016).

Tourism is a whole of related elements which consists of tourists, tourist destinations, travel, industry and so on which are tourism activities (Devy, 2017). Tourism is a social, cultural and economic phenomenon that occurs due to the movement of people / groups to a country or place outside the environment, usually for personal or business / professional purposes. Without tourist attractions, there will be no tourist visits, and vice versa. Tourism actors involved in the tourism market include tourists, the tourism industry, supporting tourism services, government, local communities and nongovernmental organizations / NGOs (Damanik and Weber, 2006 in Kuhaja, 2014).

Tourism managers, both from the private and government sectors experience the same obstacles in dealing with disasters. Tourism managers or tourism institutions are a basic aspect of tourism development efforts (Ristiawan, 2019). Synergy between formal and informal institutions can make tourism more well organized, especially in overcoming disasters (Aulia, 2010). Natural disasters and natural beauty are two things that are very popular, not only in Indonesia but also around the world, disaster is a tragedy for human life.

The definition of disaster based on Undang-Undang RI Nomer 24 of 2007 concerning that Disaster Management is an events or series of events that threaten and disrupt people's lives and livelihoods which are caused, either by natural factors and / or nonnatural factors as well as human factors, resulting in human casualties, environmental damage, property losses, and psychological impacts. that disasters are caused by natural, non-natural, and human factors. Therefore, Undang-Undang RI Nomer 24 of 2007 also defines natural disasters, non-natural disasters and social disasters.

Natural disasters that frequently hit Indonesian tourist destinations are a series of events that create a high level of uncertainty and threat (Kurniasari, 2017). Disasters occur when the available resources or capacities are seriously insufficient to deal with threats that cause loss and loss of life, material and the environment. This situation is the result of a decline in the ecological, economic, social and political fields

\section{RESEARCH METHOD}

This research uses qualitative data collection methods, but is supported by some quantitative data. This method focuses on phenomena that come from the experience of tourists. This method consists of several processes, including: finding a data collection strategy, determining how to collect data, analyzing and interpreting it. Qualitative research methods are more appropriate for gaining a deeper understanding of a phenomenon. This qualitative research has adopted a case study approach that is used to examine individuals, groups, organizations or events that are the 
object of study (Wimmer \& Dominic, 2011). The basic reason for using a case study approach is to better understand social phenomena such as possibilities (Yin, 2014). Quantitative data were obtained from the source of the Central Statistics Agency and the manager of the tourist attraction in the form of a report consisting of numbers. This research also used desk study that analyzes qualitative secondary data from online media. In recent years, research using digital data has grown rapidly along with the development of communication and information technology (Corti \& Fielding, 2016).

\section{RESULTS AND DISCUSSION}

Natural disasters such as earthquakes and volcanoes cannot predict their arrival. Since long time ago, this disaster was a natural event that caused a lot of material and non-material losses. Natural disasters are unexpected events that often occur in Indonesia. However, the handling is still not optimal. Disasters will bring bad conditions for affected communities such as neglected refugees, inadequate refugee camps, food shortages, shortages of tents, blackouts, lack of clean water, damaged roads, neglected toddlers, difficulties in access to health, incomplete information and sometimes even occur. looting. The parties concerned should be able to learn from time to time how to handle properly when a disaster strikes. The Indonesian nation is a nation that lives above disaster. For that we need institutions that have been formed to deal with disasters spontaneously in the event of a disaster. However, in its implementation it is not easy to do because of the various conditions and levels of disaster damage.

West Sumatra Province is one of the archipelagic regions in Indonesia which has a very complex geological structure. This condition is caused by its location in the collision area of 2 large tectonic plates, namely the Indo-Australian plate in the southern part and the Eurasian plate in the north which is marked by the presence of tectonic earthquake centers in the Mentawai Islands Regency and its surroundings (BPBD, 2012). The collision of these two large plates then causes other tectonic symptoms, namely the magmatic arc which is marked by the appearance of the Bukit Barisan mountain range and its volcanic mountains and large Sumatran faults that extend in the direction of the collision zone of the two plates, namely North-South.

The latest Rencana Pengelolaan Bencana (RPB) West Sumatera Province report for 2008-2012 states that the potential for natural disasters includes: earthquakes, tsunamis, floods, hurricanes / tornadoes, tidal waves, drought, landslides, volcanic eruptions, forest and land fires, as well as beach abrasion.

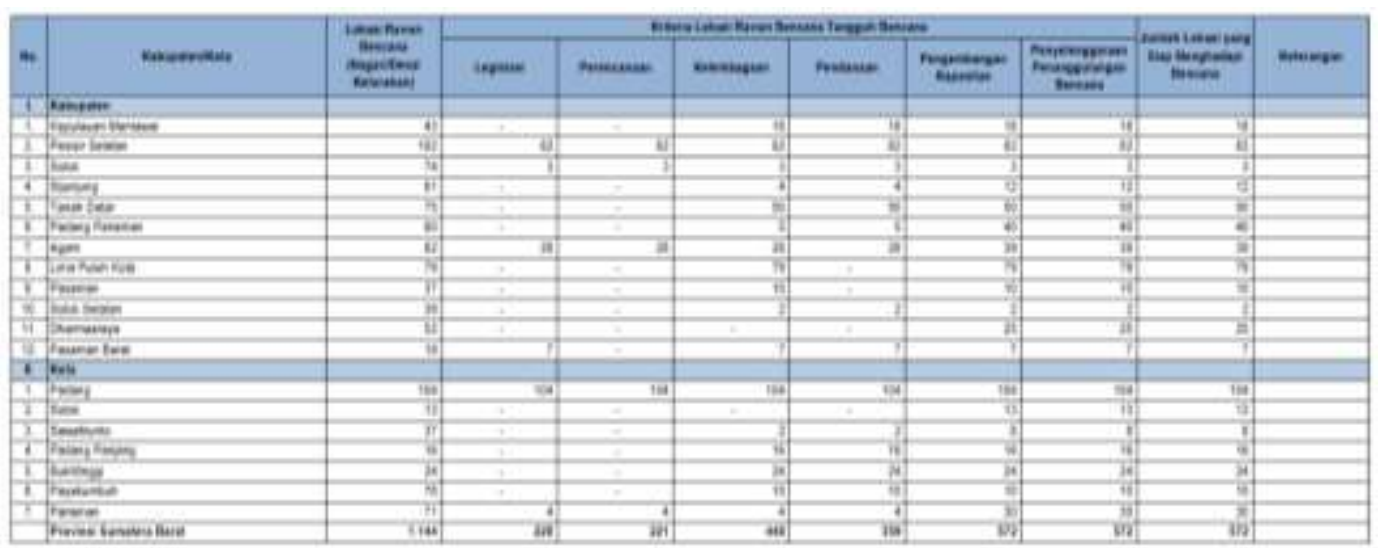

Figure 1. Recapitulation of Disaster Threats in West Sumatra Province Source: BPBD Sumbar, 2016

Almost all districts and cities in West Sumatra Province are threatened with disasters, the data above shows that the least disaster threat is Solok City, only 13 threats. The highest disaster threat is in Pesisir Selatan Regency, which is 182 threats. The city of Solok has the smallest number of threats, in other words the government should be prepared for any possibility of such a small disaster. Every government sector in the City of Solok should be able to overcome disaster problems that arise, so as not to harm the community. 
In fact, the preparation for the threat of disaster has not been optimal, some disaster has completely stopped the tourism sector, shutting down all tourist movements. Tourist attraction managers are not ready to face various threats, natural or man-made. Tourism managers cannot do anything, the condition that occurs after attack is that members of the public are prohibited from traveling, including for tourism activities.

Now, tourism managers need to adapt, make peace and prepare themselves to revive their destination in new ways. Tourism only runs when there are tourist visits, without tourists the entire tourism economy stops. Managers can suffer losses, even neglect tourist attractions due to lack of maintenance. The current condition of West Sumatra tourism is in a position like starting again, even though in reality conditions have gradually improved. The closure of tourist destinations in various regions, including West Sumatra, has reopened. The closure of tourist destinations occurs in all regions, this has led to several conditions, which are detrimental and beneficial to managers. The closure of tourist destinations during the pandemic has stopped the economic cycle of tourism entrepreneurs, no tourists equals no income and profit. The tourism business managers are losing money due to this condition. The plus side is that destinations find a period of rest to improve the environment and create more attractive attractions while awaiting the reopening of tourist travel.

Tourism managers now realize that there are several stages to be able to rise after a disaster. First, managers must be able to identify the threat of disaster in their area, make a social map of the possibility of such a disaster. This helps managers to prevent, mitigate, anticipate, and make early warnings so as not to create casualties and other resources. Managers also realize that after an unexpected disaster occurs, what is needed is a disaster response, finding ways to get help immediately, and carrying out recovery as soon as possible. Disaster management begins with planning that includes scenarios that will be carried out when a disaster occurs, for example, a small disaster has a different response to a larger disaster. Planning requires historical data of disasters that befell the location. In addition, in planning, it is necessary to involve tourism parties and parties in the disaster sector to ensure that cooperation can be carried out to reduce greater impacts. Local organizations also need to be involved in dealing with all kinds of crises so that when a crisis occurs they can determine steps to minimize losses around their area.

When a disaster occurs, the implementation of disaster management in the field requires the preparedness of the parties involved at the disaster location. The impact of a disaster cannot predict the level of damage that will be experienced in an area. Disaster is something that is complex, and when a disaster occurs, the atmosphere can become chaotic and out of control at all. However, with planning that has been carried out by various elements, it will be able to reduce the adverse impacts that will occur. It is possible that training local organizations in disaster mitigation can increase local community participation in reducing greater impacts. However, if it turns out that the disaster that comes is bigger and beyond prediction, it could be that the local community will depend on outsiders.

However, what is no less important is that coordination between tourists and local communities can reduce panic when a disaster occurs. Leadership is needed in mobilizing both human and non-human resources. Good leadership when a disaster occurs will build the trust of the parties concerned so that they can be involved in handling crisis emergencies. Tourism is a business that involves many parties from the local level to the national level, each of which has a different organizational structure.

Collaboration between parties, especially government, private sector, and NGOs in forming resilient communities with disasters is important to do. In the pre-event or pre-disaster stage, local institutions, including the community, government, and non-governmental organizations, play a major role in mitigation or prevention. Realizing the risk of disasters that exist in West Sumatra and threatening tourism, it is necessary to implement mitigation to minimize the consequences of a disaster.

\section{CONCLUSION}

Some disaster has brought tourism around the West Sumatera Province to a halt, along with the closure of mass transport routes. Nobody expected that the world in general and West Sumatra in particular would be affected by 
this disaster. The cessation of tourism and the not yet ready destinations to receive new era tourists show that awareness of the threat of disaster has not yet been established. One indicator of awareness is the emergence of a manager's creative ideas to build, reconstruct, or rearrange the destination. When tourism reopens, travel back is easy, tourists come back to their destinations. Post-disaster recovery policies in tourism areas include the rehabilitation, reconstruction and recovery stages to build back better, namely when the industry can function normally again, so that the community can carry out its economic functions.
From the above discussion it can be concluded that collaboration involving many parties in disaster management is needed to reduce the adverse effects of earthquakes. Collaboration between parties, especially government, private sector, and NGOs in forming resilient communities with disasters is important to do. In the pre-event or pre-disaster stage, local institutions, including the community, government, and non-governmental organizations, play a major role in mitigation or prevention.

\section{REFERENCE}

[1] Aulia, Tia Oktaviani Sumarna. (2010). Kearifan Lokal dalam Pengelolaan Sumberdaya Air di Kampung Kuta. Bogor: Institut Pertanian Bogor.

[2] Becken, S. (2012). Climate Change and Tourism-Advances in Knowledge and Practice. New Zealand: Lincoln University

[3] BPBD Sumbar. (2016). Rencana Strategis Satuan Kerja Perangkat Daerahbadan Penanggulangan Bencana Daerahprovinsi Sumatera Barattahun 2016-2021. Renstra Bpbd Prov. Sumatera Barat Tahun 2016-2021. Keputusan Kepala Pelaksana Badan Penanggulangan Bencana Daerah Provinsi Sumatera Barat nomor: 050/75/Set/2016.

[4] BPBD. (2012). Rencana Kontinjensi: Menghadapi Bencana Tsunami Provinsi Sumatera Barat. BPBD Sumatera Barat.

[5] Buckley, R., U. Gretzel, D., Scott, D., Weaver, and S. Becken. (2015). Tourism megatrends. Tourism Recreation Research, 40 (1), pp. 59-70

[6] Cholik, M. A. (2017). The development of tourism industry in Indonesia: Current problems and challenges. European Journal of Research and Reflection in Management Sciences, 5(1), 49-59

[7] Corti, L., \& Fielding, N. (2016). Opportunities From the Digital Revolution: Implications for Researching, Publishing, and Consuming Qualitative Research. SAGE Open, 1-13.

[8] Debski, Maciej \& Nasierowski, Wojciech. (2017). Criteria for The Selection of Tourism Destinations by Students from Different Countries. Foundation of Management Journal, Vol. 9, Page: 317-330.

[9] Incera, A. C., \& Fernández, M. F. (2015). Tourism and income distribution: Evidence from a developed regional economy. Tourism Management, 48, 11-20.

[10] Kuhaja, Tendy. (2014). Kajian Kelembagaan dalam Pengembangan Pariwisata Pantai yang Berkelanjutan. Jurnal Pembangunan Wilayah dan Kota, Vol. 10, No. 3, Page: 278-292.

[11] Kurniasari, Nani. 2017. Strategi Penanganan Krisis Kepariwisataan dalam Kebijakan Badan Nasional Penanggulangan Bencana (BNPB). Jurnal MediaTor, Vol 10 (2), page: 177-189

[12] Mariyono, J. (2017). Determinants of demand for foreign tourism in Indonesia. Jurnal Ekonomi Pembangunan: Kajian Masalah Ekonomi dan Pembangunan, 18 (1), 82.

[13] Nugroho, D. U., R, N. U. P., Rengganis, N. S., \& Wigati, P. A. (2013). Sekolah Petra (Penanganan Trauma) bagi Anak Korban Bencana Alam. Jurnal IImiah Mahasiswa, 2(2), 97-101

[14]

Oktavio, A. (2017). Pengaruh

business process reengineering terhadap business process performance pada hotel budget di Surabaya. Jurnal IImiah Manajemen dan Akuntansi: Ekonomika', 4 (2), 163-175

[15] Ristiawan, Rucitarahma. (2019). Perencanaan Pengelolaan Wisata Pedesaan di Desa Bumiaji, Kota Batu, Kabupaten Malang, Jawa Timur. Jurnal Bakti Budaya, Vol. 2, No, 2, Page: 113127.

[16] Sutanto, D. H. (2016). Pentingnya promosi guna meningkatkan minat wisatawan wisata sejarah di Kota Lama Semarang. Jurnal Pariwisata Pesona, 1(1), Pages: 1-17. 
[17] UNWTO. 2020. Glossary of Tourism Term. Accessed on dari https://www.unwto.org/glossary-tourism-terms pada 9 Agustus 2020, at 21:00.

[18] Wimmer, R.D., \& Dominic, J.R. 2011. Mass Media Research: An Introduction. Wadsworth, USA.

[19] Yin, R.K. 2014. Case Study Research: Design and Methods, 5th Edition. Sage Publications, USA. 